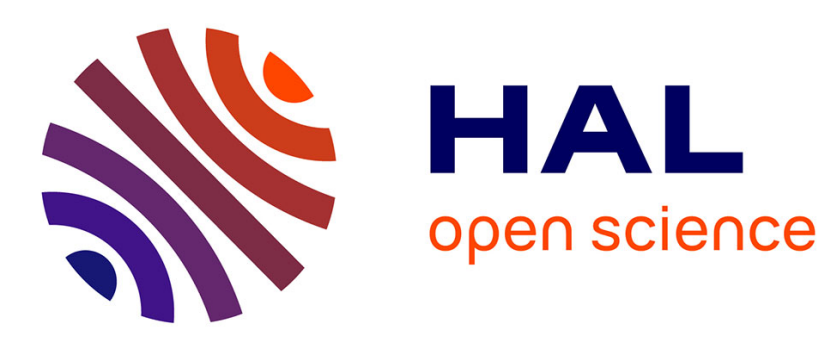

\title{
Dancing droplets: Autonomous surface tension-driven droplet motion
}

\author{
Nate J. Cira, Adrien Benusiglio, Manu Prakash
}

\section{To cite this version:}

Nate J. Cira, Adrien Benusiglio, Manu Prakash. Dancing droplets: Autonomous surface tension-driven droplet motion. Physics of Fluids, 2014, 26 (9), 10.1063/1.4894407 . hal-01338282

\section{HAL Id: hal-01338282 \\ https://hal.science/hal-01338282}

Submitted on 28 Jun 2016

HAL is a multi-disciplinary open access archive for the deposit and dissemination of scientific research documents, whether they are published or not. The documents may come from teaching and research institutions in France or abroad, or from public or private research centers.
L'archive ouverte pluridisciplinaire HAL, est destinée au dépôt et à la diffusion de documents scientifiques de niveau recherche, publiés ou non, émanant des établissements d'enseignement et de recherche français ou étrangers, des laboratoires publics ou privés. 


\section{AIP $\mid$ Physics of Fluids}

\section{Dancing droplets: Autonomous surface tension-driven droplet motion}

Nate J. Cira, Adrien Benusiglio, and Manu Prakash

Citation: Physics of Fluids 26, 091113 (2014); doi: 10.1063/1.4894407

View online: http://dx.doi.org/10.1063/1.4894407

View Table of Contents: http://scitation.aip.org/content/aip/journal/pof2/26/9?ver=pdfcov

Published by the AIP Publishing

Articles you may be interested in

Evaporation-driven low Reynolds number vortices in a cavity

Phys. Fluids 26, 033102 (2014); 10.1063/1.4868546

Oscillations of a sessile droplet in open air

Phys. Fluids 25, 112106 (2013); 10.1063/1.4829025

Marangoni flow in an evaporating water droplet

Appl. Phys. Lett. 91, 124102 (2007); 10.1063/1.2789402

Dancing droplets onto liquid surfaces

Phys. Fluids 18, 091106 (2006); 10.1063/1.2335905

Laser-induced motion in nanoparticle suspension droplets on a surface

Phys. Fluids 17, 102106 (2005); 10.1063/1.2098587

\section{A WHOLE NEW LOOK FOR PHYSICS TODAY MAGAZINE COMING JANUARY 2016}

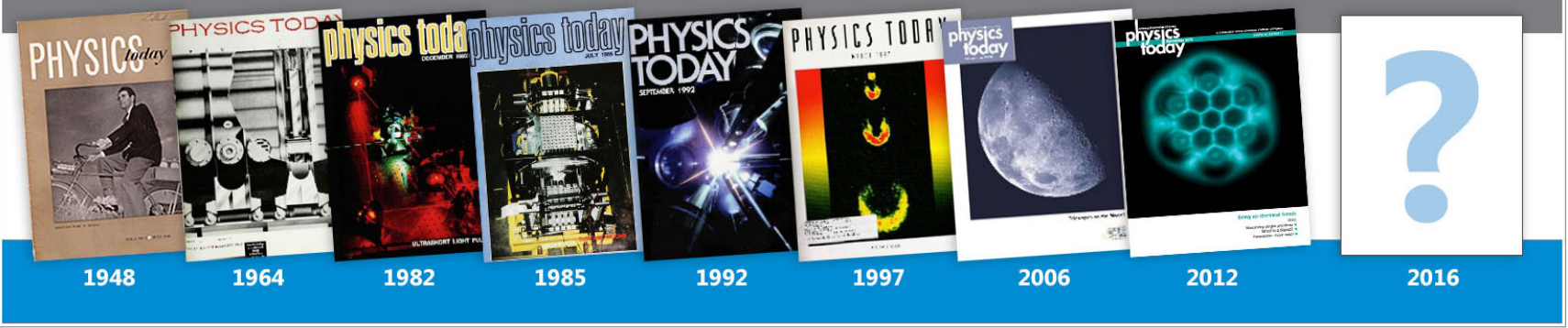



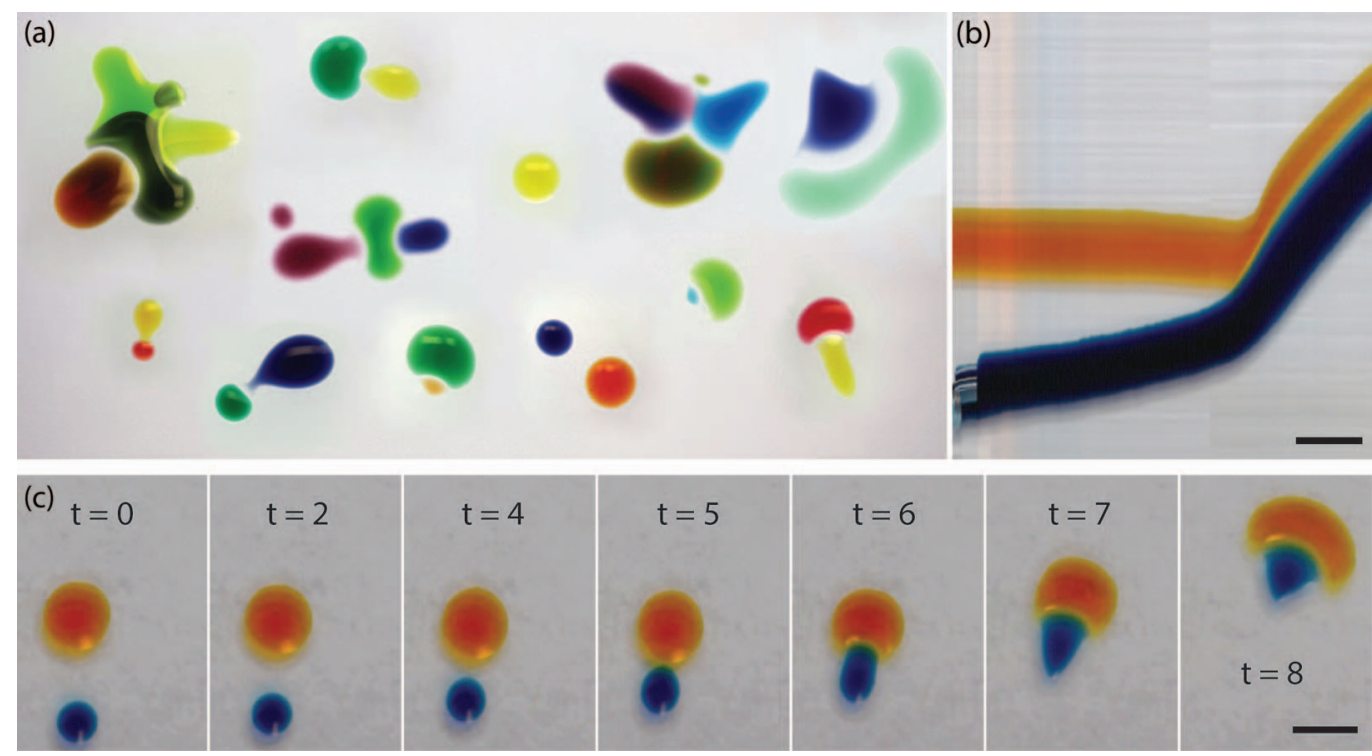

FIG. 1. (a) Assembled collage of droplet interactions. Droplets of PG and water were mixed at various dilution dyed with food coloring and allowed to autonomously interact. Images were assembled into a single frame, typical droplet volume 0.1-5 $\mu$ l. (b) Kymograph of two droplets interacting over $18 \mathrm{~s}$ (blue droplet 25\% PG, orange droplet $1 \%$ PG, scale bar $3 \mathrm{~mm}$ ). The motion can be broken into a long-range phase before droplet contact and a short-range phase after droplet contact. (c) Sequence of images from two droplets interacting (blue droplet 25\% PG, orange droplet 1\% PG, scale bar $3 \mathrm{~mm}$ ). $\mathrm{t}=0 \mathrm{~s}$ to $\mathrm{t}=5 \mathrm{~s}$, short-range interactions. $\mathrm{t}=5 \mathrm{~s}$ to $\mathrm{t}=8 \mathrm{~s}$, long-range interactions. (Multimedia view) [URL: http://dx.doi.org/10.1063/1.4894407.1]

\title{
Dancing droplets: Autonomous surface tension-driven droplet motion
}

\author{
Nate J. Cira, Adrien Benusiglio, and Manu Prakash ${ }^{\text {a) }}$ \\ Department of Bioengineering, Stanford University, Stanford, California 94305-5431, USA
}

(Received 15 August 2014; published online 19 September 2014)

[http://dx.doi.org/10.1063/1.4894407]

When droplets of water and food coloring at different concentrations are deposited on a clean glass slide they enter a complex dance (Fig. 1(a)).

We reproduce this phenomenon by using a two-component mixture of propylene glycol and water deposited on corona treated (Electro-Technic BD-20AC) glass slides and record the phenomena using a Cannon 5D Mark II camera with a $50 \mathrm{~mm}$ macro lens. When $2 \mathrm{~mm}$-size droplets are deposited apart, they move towards each other. This attraction happens even if the droplets have exactly the same concentration, leading to the coalescence of both droplets into one. If droplets have different concentrations, they enter a chasing phase, ${ }^{1}$ where the droplet of smaller water concentration chases the other for up to several minutes (Figs. 1(b) and 1(c)). Two droplets will attract each other across a gap in the substrate illustrating that long-range attraction is vapor mediated. When two droplets are deposited on the glass, each one evaporates and forms a gradient of water vapor ${ }^{2}$ (water is 100 times more volatile than propylene glycol). The vapor gradient from one droplet destabilizes the other, giving rise to an attraction between the droplets, even if they have the same concentration.

\footnotetext{
a) Author to whom correspondence should be addressed. Electronic mail: manup@stanford.edu
} 
N.J.C. is supported by an NSF GRFP Fellowship. A.B. is supported by the Pew Foundation. M.P. is supported by the Pew Program in Biomedical Sciences, Terman Fellowship, and Gordon and Betty Moore Foundation.

${ }^{1}$ H. Riegler and P. Lazar, "Delayed coalescence behavior of droplets with completely miscible liquids," Langmuir $\mathbf{2 4 ,}$ 6395-6398 (2008)

${ }^{2}$ H. Hu and R. G. Larson, "Evaporation of a sessile droplet on a substrate," J. Phys. Chem. B 106, 1334-1344 (2002). 